\title{
A survey on factors influencing city branding
}

\author{
Seyed Mohsen Mahmoudzadeh ${ }^{a^{*}}$, Mahmoud Samiei Nasra ${ }^{a}$, and Mostafa Hashemi ${ }^{\text {b }}$
}

${ }^{a}$ Department of Management, South Tehran Branch, Islamic Azad University, Tehran, Iran ${ }^{b}$ MA student at Islamic Azad University (IAU), Kish International Branch, Kish Island, Iran

\section{H R O N I C L E A B S T R A C T}

Article history:

Received January 20, 2014

Accepted 30 August 2014

Available online

September 12014

City branding

AHP

City development

\begin{abstract}
Nowadays, the issue of "globalization" is entering to all areas in the world. In addition to products and companies, cities and countries also have the opportunity to see themselves as important actors in international arena. Places define their positions in different fields like business, leisure and recreation, educational opportunities, living, etc. This paper presents an empirical study to introduce city branding as one of the solutions to join globalization process. The method of this research is based on the "descriptive-analytic" and utilize the available literature and experts' opinions to prioritize the influencing factors of city branding. We use Delphi consensus methods and technique of analytical hierarchy process to evaluate the factors. Finally, the results of the study indicate that security, transportation and mental creativity are the weakest fields and business and shopping facilities are strong fields of city branding in metropolitan of Tehran.
\end{abstract}

\section{Introduction}

Nowadays, cities all over globe include more and more marketing techniques in their administration practice and governing philosophy. The transfer of marketing knowledge, however, to the operational environment of cities creates some challenges, mostly due to the specific nature of places in general and cities in specific as marketable assets (Kavaratzis, 2004; Anholt, 2006; Braun, 2008). Nowadays, the issue of "globalization" is entering to all areas in the world. In addition to products and companies, cities and countries also have the opportunity to see themselves as important actors in international arena (Ashworth \& Voogd, 1990; Hankinson \& Cowking, 1993). Embacher and Buttle (1989) investigated the suitability of repertory grid technique to destination image research. The study tried to find out how tourists construed destination countries and reported how they perceived Austria in terms of the constructs generated. Gallarza et al. (2002) presented a review and investigation of the concept and measurement of destination image, within an intra-disciplinary marketing perspective. They presented a conceptual model featuring its complex, relativistic multiple and dynamic nature as a more comprehensive framework of destination image. Ashworth and

*Corresponding author.

E-mail addresses: mohsenmahmoudzadeh@gmail.com (S. M. Mahmoudzadeh) 
Kavaratzis (2009) explained the rise of city branding and the reasons of its popularity and identified necessary similarities between these two forms of branding.

\section{The proposed study}

In this paper, we present an empirical investigation to prioritize different factors influencing on city branding using analytical hierarchy process (AHP) (Saaty, 1988, 1990). The study considers seven factors influencing on city branding development (Knox \& Bickerton, 2003; Ward, 1998; Raubo, 2010), which are briefly discussed as follows (See Fig. 1),

Nature: Access to recreational open spaces clean, plenty of parks and facilities, mass flow, the Green Belt, Natural Attractions (Embacher \& Buttle, 1989),

Creativity and innovation in business: Good place to do business, innovative business process improvements to local industries, abundant employment opportunities (Embacher \& Buttle, 1989),

Purchase opportunity: Choices for shopping, good shopping centers, variety of restaurants (Hankinson, 2001; Hankinson \& Cowking, 1993),

Transportation: Lack of adequate communication networks, traffic flowing, lack of any problem for citizens during road construction, road maintenance and quick repairs (Kozak, 2003),

Cultural activities: Cultural events and festivals, cultural centers (Hankinson, 2001),

Governmental services: Adequate access to health care, educational facilities, availability of plenty of public transportations according to the therapeutic needs of the elderly, reliable energy sources (Santos et al., 2007; Merrilees et al., 2009; Smyth, 2005),

Security: Feeling of security among citizens (Zhang \& Zhao, 2009).

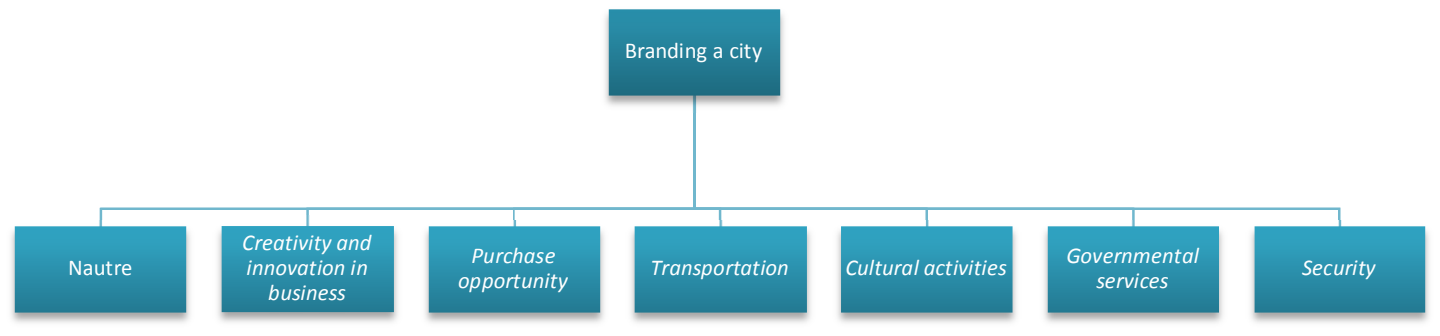

Fig. 1. The proposed studv of the paper

As stated before, the proposed study of this paper uses analytical hierarchy process (AHP) to rank the effects of seven different factors. Table 1 demonstrates the results of pair-wise comparison and Fig. 2 summarizes the results of our ranking.

Table 1

The summary of pairwise comparison

\begin{tabular}{|c|c|c|c|c|c|c|c|c|}
\hline Factor & Nature & $\begin{array}{c}\text { Creativity and innovation } \\
\text { in business }\end{array}$ & $\begin{array}{c}\text { Purchase } \\
\text { opportunity }\end{array}$ & Transportation & $\begin{array}{l}\text { Cultural } \\
\text { activities }\end{array}$ & $\begin{array}{l}\text { Governmental } \\
\text { services }\end{array}$ & Security & $\begin{array}{c}\text { Final } \\
\text { weight }\end{array}$ \\
\hline Nature & 1.00 & 0.90 & 0.70 & 1.20 & 0.48 & 0.82 & 1.70 & 0.97 \\
\hline $\begin{array}{l}\text { Creativity and } \\
\text { innovation in } \\
\text { business }\end{array}$ & 1.11 & 1.00 & 2.00 & 1.60 & 1.83 & 1.51 & 2.11 & 1.59 \\
\hline $\begin{array}{l}\text { Purchase } \\
\text { opportunity }\end{array}$ & 1.43 & 0.50 & 1.00 & 1.23 & 1.55 & 1.50 & 1.60 & 1.26 \\
\hline Transportation & 0.83 & 0.63 & 0.81 & 1.00 & 0.26 & 0.80 & 1.15 & 0.78 \\
\hline Cultural activities & 1.20 & 0.55 & 0.65 & 1.75 & 1.00 & 1.39 & 1.50 & 1.15 \\
\hline $\begin{array}{l}\text { Governmental } \\
\text { services }\end{array}$ & 1.22 & 0.66 & 0.67 & 1.25 & 0.72 & 1.00 & 1.89 & 1.06 \\
\hline Security & 0.59 & 0.47 & 0.63 & 0.87 & 0.67 & 0.53 & 1.00 & 0.68 \\
\hline
\end{tabular}




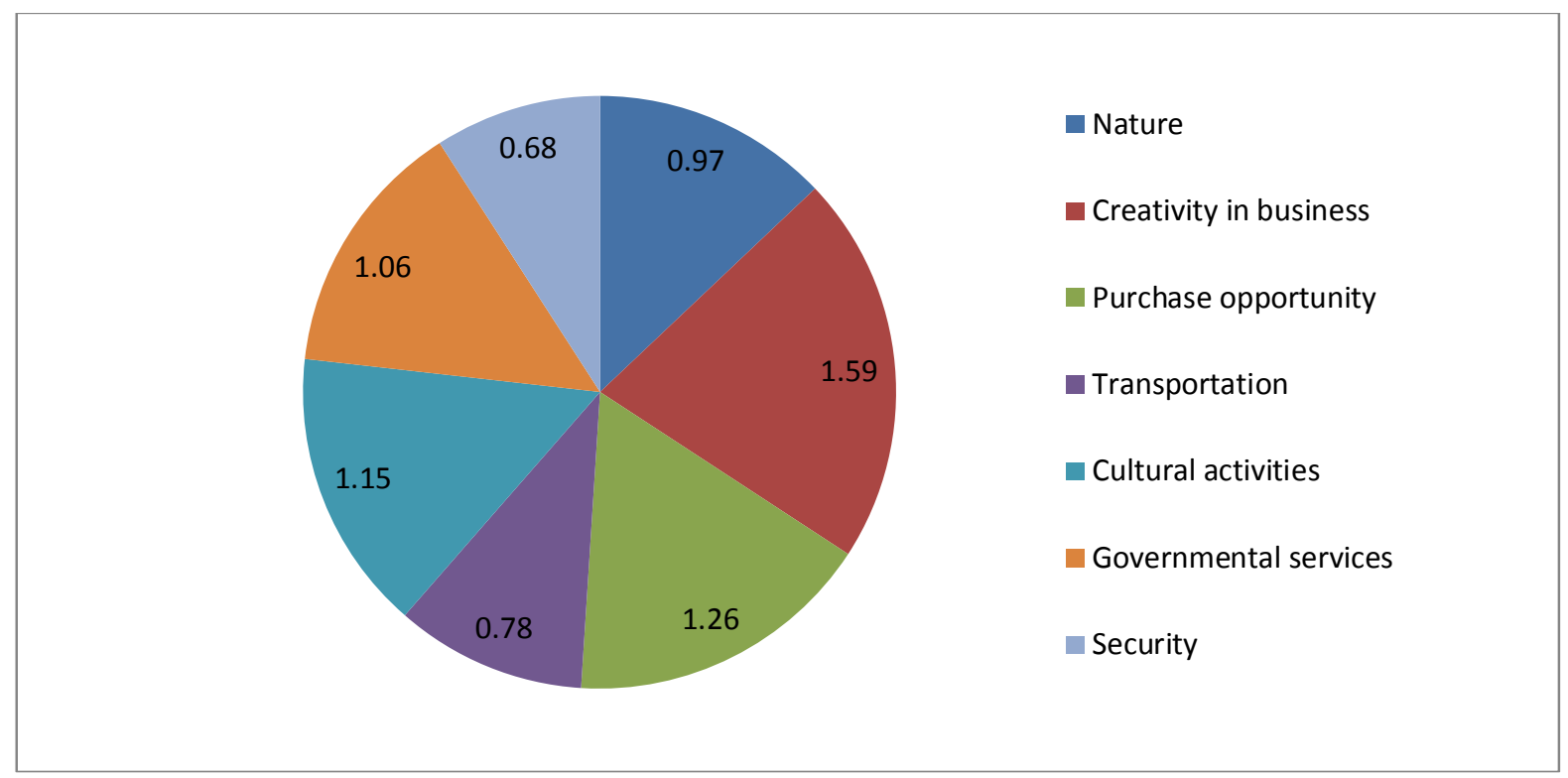

Fig. 2. The results of ranking various factors

As we can observe from the results of Fig. 2, creativity and innovation in business development is number one priority followed by purchase opportunity, cultural activities and governmental services. The consistency ratio has been considered as 0.056 , which is well below 0.1 and this confirms the overall survey.

\section{Discussion and conclusion}

In this paper, we have presented an empirical investigation to rank different factors influencing on city branding. The proposed study has considered seven factors including nature, creativity and innovation in business, purchase opportunity, transportation, cultural activities, governmental services and security influencing on development of city branding. The study has accomplished a pairwise comparison by performing a survey among 15 people and the results of the survey has confirmed that creativity and innovation in business development is number one priority followed by purchase opportunity, cultural activities and governmental services. The results of our study are consistent with Rainisto (2003), Kavaratzis (2004) and Kozak (2003). Based on the survey accomplished, we propose some methods for developing city branding in city of Tehran, Iran and Table 2 shows the summary of our findings.

Table 2

The summary of possible actions for city development

\begin{tabular}{ll}
\hline Factor & Suggestion \\
\hline Security & Infrastructure development \\
Good transportation & \\
Nature & Further development \\
\hline Governmental development & \\
\hline Creativity and innovation in business development & Sustainable development \\
Purchase opportunities & \\
\hline Cultural activities & \\
\hline
\end{tabular}

As we can observe from the results of Table 2, for three factors of security, good transportation and nature related issues; we recommend further development in infrastructures. There is no doubt that governmental development could significantly contribute to city branding and finally, sustainable development could contribute on having more creative ideas, purchasing opportunities as well as development in cultural activities. 


\section{Acknowledgement}

The authors would like to thank the anonymous referees for constructive comment on earlier version of this paper.

\section{References}

Ashworth, G. J., \& Voogd, H. (1990). Selling the city. London: Bellhaven.

Ashworth, G., \& Kavaratzis, M. (2009). Beyond the logo: Brand management for cities. Journal of Brand Management, 16(8), 520-531.

Anholt, S. (2006). Competitive identity: The new brand management for nations, cities and regions. Palgrave Macmillan.

Braun, E. (2008). City Marketing: Towards an integrated approach (No. EPS-2008-142-ORG). Erasmus Research Institute of Management (ERIM).

Embacher, J., \& Buttle, F. (1989). A repertory grid analysis of Austria's image as a summer vacation destination. Journal of Travel Research, 27(3), 3-7.

Gallarza, M. G., Saura, I. G., \& Garcí a, H. C. (2002). Destination image: towards a conceptual framework. Annals of tourism research, 29(1), 56-78.

Hankinson, G., \& Cowking, P. (1993). Branding in action. Maidenhead: McGraw-Hill.

Hankinson, G. (2001). Location branding: A study of the branding practices of 12 English cities. The Journal of Brand Management, 9(2), 127-142.

Kavaratzis, M. (2004). From city marketing to city branding: Towards a theoretical framework for developing city brands. Place branding, 1(1), 58-73.

Kavaratzis, M., \& Ashworth, G. J. (2005). City branding: an effective assertion of identity or a transitory marketing trick?. Tijdschrift voor economische en sociale geografie, 96(5), 506-514.

Kavaratzis, M. (2004). From city marketing to city branding: Towards a theoretical framework for developing city brands. Place branding, 1(1), 58-73.

Knox, S., \& Bickerton, D. (2003). The six conventions of corporate branding. European Journal of Marketing, 37(7/8), 998-1016.

Kotler, P., Hamlin, M. A., Rein, I., \& Haider, D. H. (2002). Marketing Asian places: attracting investment, industry, and tourism to cities, states, and nations. John Wiley \& Sons.

Kozak, M. (2003). Measuring tourist satisfaction with multiple destination attributes. Tourism Analysis, 7(3-4), 229-240.

Merrilees, B., Miller, D., \& Herington, C. (2009). Antecedents of residents' city brand attitudes. Journal of Business Research, 62(3), 362-367.

Rainisto, S. K. (2003). Success factors of place marketing: A study of place marketing practices in Northern Europe and the United States. Helsinki University of Technology.

Raubo, A. N. N. A. (2010). City Branding and Its Impact on City's Attractiveness for External Audiences. Erasmus University.

Saaty, T. L. (1988). What is the analytic hierarchy process? (pp. 109-121). Springer Berlin Heidelberg.

Saaty, T. L. (1990). How to make a decision: the analytic hierarchy process. European journal of operational research, 48(1), 9-26.

Santos, L. D., Martins, I., \& Brito, P. (2007). Measuring subjective quality of life: a survey to Porto's residents. Applied Research in Quality of Life, 2(1), 51-64.

Smyth, H. (2005). Marketing the city: the role of flagship developments in urban regeneration. Taylor \& Francis.

Ward, S. V. (1998). Selling places: the marketing and promotion of towns and cities, 18502000 (Vol. 23). Taylor \& Francis.

Zhang, L., \& Zhao, S. X. (2009). City branding and the Olympic effect: A case study of Beijing. Cities, 26(5), 245-254. 